\title{
Oxygen distribution and bioirrigation in Arctic fjord sediments (Svalbard, Barents Sea)
}

\author{
Bo Barker Jørgensen ${ }^{1, *}$, Ronnie Nøhr Glud ${ }^{2}$, Ola Holby ${ }^{3}$ \\ ${ }^{1}$ Max Planck Institute for Marine Microbiology, Celsiusstr. 1, 28359 Bremen, Germany \\ ${ }^{2}$ Marine Biological Laboratory, University of Copenhagen, Strandpromenaden 5, 3000 Helsingør, Denmark \\ ${ }^{3}$ Department of Environmental and Energy Systems, Karlstad University, 65188 Karlstad, Sweden
}

\begin{abstract}
The penetration of oxygen into silty fjord sediments from northern Norway and SW Svalbard was studied at 6 sites during a research cruise to the northern Barents Sea. Profiles of oxygen were measured by microelectrodes on retrieved sediment cores in a thermostated flow aquarium and used to develop composite, 2-dimensional images of the oxygen distribution. Oxygen penetrations ranged from 3 to $11 \mathrm{~mm}$ with a mean depth of 6 to $8 \mathrm{~mm}$. The mean diffusive oxygen uptake rates across the sediment-water interface ranged from 2.8 to $13.4 \mathrm{mmol} \mathrm{O}_{2} \mathrm{~m}^{-2} \mathrm{~d}^{-1}$. The diffusive flux accounted for 60 to $95 \%$ of the total oxygen uptake of the sediments as measured in situ by a flux chamber lander. The sediments were densely populated by fauna such as tube-dwelling polychaetes. Inhabited and relict tubes of 1 to $2.5 \mathrm{~mm}$ diameter reached densities of up to $1 \mathrm{~cm}^{-2}$, and about $15 \%$ of all oxygen microprofiles showed evidence of advective oxygen flow through the tubes. Based on oxygen microprofiles and data on burrow geometry and density, burrows extending down into the anoxic sediment extended the oxic sediment volume by 2 to $10 \%$ and thereby enhanced the oxygen flux. Anoxic microenvironments were not detected, but during inactivity of polychaetes their tubes became depleted in oxygen relative to the surrounding sediment.
\end{abstract}

KEY WORDS: Oxygen uptake $\cdot$ Marine sediment $\cdot$ Polychaete burrow $\cdot$ Microelectrode $\cdot$ Diffusion

\section{INTRODUCTION}

Coastal waters in the high Arctic are characterized by permanently low temperature, by extensive ice cover in winter, and by a relatively short summer period of phytoplankton growth, yet, the primary productivity in Arctic waters may be comparable to that measured at temperate latitudes where there is no significant ice cover (Eilertsen et al. 1989, Sakshaug et al. 1994). Organic sedimentation is low under the winter ice whereas high sedimentation occurs when the ice breaks and during the short summer period (Atkinson \& Wacasey 1987, Hebbeln \& Wefer 1991). The sediments thus receive a strong pulse of organic material following the late spring phytoplankton bloom and additional material during the summer.

Temperate coastal environments with strong seasonal variation in bottom water temperature are char- acterized by high rates of sediment mineralization and oxygen uptake during summer and low rates during winter. This variation is due to both the seasonal influx of organic material and the temperature control on metabolic rates (Thamdrup et al. 1994, 1998). In contrast, respiration rates in Arctic sediments do not appear to be limited by permanently low temperatures (Nedwell et al. 1993, Rysgaard et al. 1996, 1998, Thamdrup \& Fleischer 1998). Similar to temperate sediments, the rates of mineralization are limited by the influx of organic material, and the overall efficiency of mineralization appears to be equally high (Glud et al. 1998). Consequently, the Arctic benthic fauna and bacterial communities are well-adapted to a permanently low temperature that may be less of a stress factor than a seasonally variable temperature. Studies of the short-term regulation of aerobic and anaerobic biological processes in Arctic sediments 
have shown that the microbial populations have relatively high activity and optimal growth yield at the low in situ temperature (Rysgaard et al. 1998, Thamdrup \& Fleischer 1998, Knoblauch \& Jørgensen 1999, Arnosti \& Jørgensen 2003).

The present study of the small-scale distribution of oxygen in the Arctic sea floor was undertaken to determine the controls on benthic oxygen uptake and the role of irrigating fauna in the heterogeneity of oxygen distribution. We used oxygen microsensor analyses on laboratory-incubated sediment cores combined with diffusion calculations from oxygen gradients as the main tools for this study.

\section{MATERIALS AND METHODS}

Sampling locations. The islands of Svalbard are situated in the northern Barents Sea, and the western main island, Spitsbergen, extends from 76 to $80^{\circ}$ north. The rocky west coast of Spitsbergen is incised by deep glacial fjords with silty sediments affected by glacier runoff and drop stones. Water depths of the investigated fjord stations ranged from 78 to $329 \mathrm{~m}$ and oxygen saturation of the bottom water from 88 to $98 \%$ (Table 1). Fjords on the west coast receive relatively warm Atlantic water of up to $3^{\circ} \mathrm{C}$ in summer from the west Spitsbergen current, whereas the SE coast is affected by cold Arctic water with summer temperatures below $0^{\circ} \mathrm{C}$. At the time of sampling, the temperature of the bottom water ranged from -1.7 to $2.6^{\circ} \mathrm{C}$ in the Svalbard fjords. In the Norwegian Malangen Fjord located at $69^{\circ} \mathrm{N}$, the bottom water temperature was $7.0^{\circ} \mathrm{C}$. The phytoplankton productivity is relatively high for the high Arctic, with a long-term average for the Barents Sea of $110 \mathrm{~g} \mathrm{C} \mathrm{m}^{-2} \mathrm{yr}^{-1}$ (Sakshaug 1997) and a total range from $<25$ to $>150 \mathrm{~g} \mathrm{C} \mathrm{m}^{-2} \mathrm{yr}^{-1}$ (Eilertsen et al. 1989, Hop et al. 2002). There is a close pelagic-benthic coupling (Wassmann et al. 1996) and a high abundance of benthic invertebrate fauna, including polychaetes, bivalves and crustaceans.

The fjords of Svalbard are ice-covered during half of the year or more. Ice melting in late spring generates a salinity stratification that stabilizes the water column and initiates a spring phytoplankton bloom. During summer the primary productivity is regulated mostly by the hydrography and nutrient availability.

Sediment was sampled from 6 coastal locations of northern Norway and around SW Svalbard in the northern Barents Sea during a cruise in September 1995 with the Norwegian research vessel RV 'Jan Mayen' of Tromsø. The positions and other characteristics of the sampling stations are given in Table 1. Stn SV-1 was situated on the north coast of Norway in Malangen Fjord. The other 5 stations were situated in fjords along the south and west coasts of Spitsbergen: SV-2 in Hornsund, SV-3 in Van Mijenfjorden, SV-4 just outside of Hornsund, and SV-5 and SV-6 in Storfjorden (Fig. 1). Hornsund is semi-enclosed and strongly affected by glaciers, while Storfjorden is more open to water exchange with shelf currents. Van Mijenfjorden is nearly closed by a barrier island and has a shallow sill at the entrance.

Sediment core incubations. Sediment cores of $10 \mathrm{~cm}$ diameter and 20 to $30 \mathrm{~cm}$ depth were taken by a multicorer. After inspection, individual cores were selected that had a visibly intact sediment surface. This was evident from the natural position of small polychaete tubes, from the topography and fine structures of the sediment surface, and from clear water above the sediment. The core liner was then taped at the top to a shorter core liner of similar diameter but only $15 \mathrm{~cm}$ in length, and the core with overlying water was very carefully pushed up into the short tube. An intact core of $12 \mathrm{~cm}$ length was then submerged in a flow aquarium with thermostated bottom water from the sampling location. By pressing the open core down over a Plexiglas spacer, the core was pushed up until it was flush with the upper rim of the core liner and with the surrrounding plate that mimicked the sediment surface (Fig. 2). The incoming water flow was guided through a diffusor, made of a double $1 \mathrm{~mm}$ mesh nylon net, which created a near-linear flow of $4 \mathrm{~cm} \mathrm{~s}^{-1}$ measured at ca. $0.5 \mathrm{~cm}$ above the sediment surface by observation of the velocity of suspended particles under the dissection microscope. The aquarium was

Table 1. Positions and physical-chemical characteristics of the 6 sampling stations in northern Norway (Stn SV-1) and along SW Svalbard. -: no data. Hornsund O.: station just outside of Hornsund; Storfjorden W.: most westerly of the 2 Storfjorden stations

\begin{tabular}{|c|c|c|c|c|c|c|c|c|c|c|c|c|}
\hline \multirow[t]{2}{*}{ Stn } & \multirow{2}{*}{ Area } & \multicolumn{2}{|c|}{ Position } & \multirow{2}{*}{$\begin{array}{l}\text { Depth } \\
\text { (m) }\end{array}$} & \multicolumn{2}{|c|}{ Temperature $\left({ }^{\circ} \mathrm{C}\right)$} & \multicolumn{2}{|c|}{ Salinity } & \multicolumn{2}{|c|}{ Oxygen $(\mu \mathrm{M})$} & \multicolumn{2}{|c|}{ Oxygen saturation (\%) } \\
\hline & & Latitude & Longitude & & Surface & Bottom & Surface & Bottom & Surface & Bottom & Surface & Bottom \\
\hline SV-1 & Malangen Fjord & $69^{\circ} 29.4^{\prime} \mathrm{N}$ & $18^{\circ} 07.5^{\prime} \mathrm{E}$ & 329 & - & 7.0 & - & 34.9 & - & 289 & - & 96 \\
\hline $\mathrm{SV}-2$ & Hornsund & $76^{\circ} 58.2^{\prime} \mathrm{N}$ & $15^{\circ} 34.5^{\prime} \mathrm{E}$ & 155 & 1.2 & 2.6 & 32.6 & 34.7 & 375 & 321 & 106 & 96 \\
\hline $\mathrm{SV}-3$ & Van Mijenfjord & $77^{\circ} 45.8^{\prime} \mathrm{N}$ & $15^{\circ} 03.9^{\prime} \mathrm{E}$ & 115 & 1.8 & 0.2 & 32.3 & 34.6 & 370 & 347 & 106 & 98 \\
\hline $\mathrm{SV}-4$ & Hornsund O. & $76^{\circ} 57.7^{\prime} \mathrm{N}$ & $15^{\circ} 00.2^{\prime} \mathrm{E}$ & 138 & 0.9 & 2.8 & 32.7 & 34.7 & 374 & 326 & 103 & 98 \\
\hline $\mathrm{SV}-5$ & Storfjorden & $77^{\circ} 33.0^{\prime} \mathrm{N}$ & $19^{\circ} 05.0^{\prime} \mathrm{E}$ & 175 & - & 1.7 & - & 34.9 & - & 328 & - & 88 \\
\hline SV-6 & Storfjorden W. & $77^{\circ} 30.0^{\prime} \mathrm{N}$ & $18^{\circ} 26.0^{\prime} \mathrm{E}$ & 78 & - & 1.5 & - & 34.9 & - & 333 & - & 97 \\
\hline
\end{tabular}




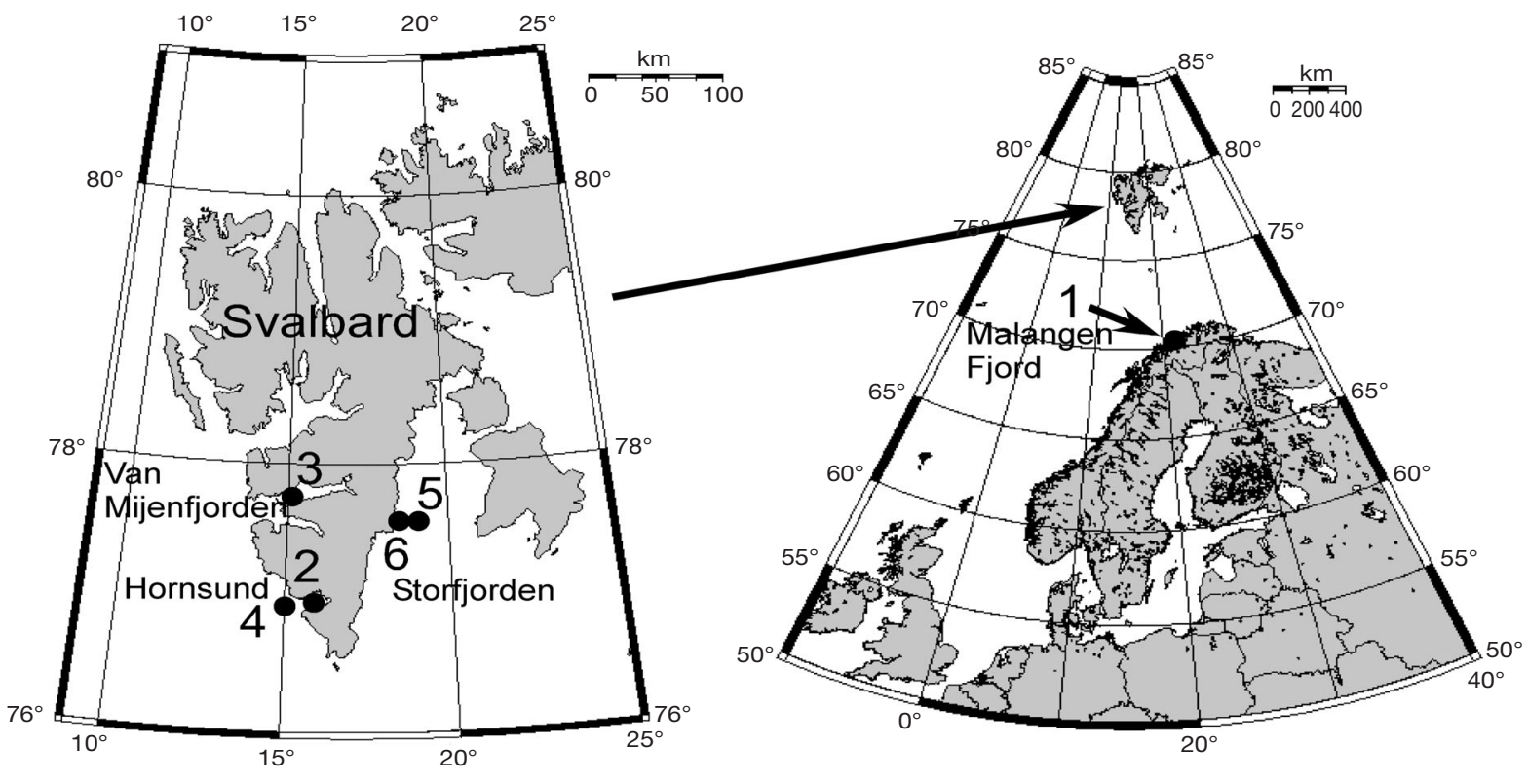

Fig. 1. Positions of 6 coastal sampling stations in the Barents Sea. Stn 1 was located in Malangen Fjord on the north coast of Norway, Stns 2 to 6 along the SW coast of Svalbard in Van Mijenfjorden (Stn 3), Hornsund (Stns 2 and 4) and Storfjorden (Stns 5 and 6)

insulated by $15 \mathrm{~mm}$ styrofoam, but had an open top to allow access for microelectrodes. A stainless steel spiral with cooling circulation was connected to a cooling bath with anti-freeze fluid. This maintained the aquarium at in situ temperature with a long-term accuracy of $\pm 0.3^{\circ} \mathrm{C}$. The circulating seawater was continuously flushed with air to maintain air saturation of oxygen. The in situ oxygen concentration of the bottom water was very close to air saturation (96 to 98\%) at most stations (Table 1). Only in the deep Storfjorden was the oxygen saturation lower $(88 \%)$. The following measurements of oxygen microprofiles were all carried out within $24 \mathrm{~h}$ after core recovery.

Oxygen microprofile measurements. Oxygen distributions in the intact sediment cores were measured by microelectrodes constructed at the Max Planck Institute in Bremen. The microelectrodes were Clark type sensors equipped with a guard cathode and an internal reference (Revsbech 1989). The sensing tip diameter was 5 to $20 \mu \mathrm{m}$, the stirring effect was 0.5 to $1 \%$, and the $90 \%$ response time was <1 s. Linear calibration was made between $100 \%$ air saturation in the flowing water of the aquarium and zero oxygen at depth in the sediment. The sensors were positioned with a vertical angle of $30^{\circ}$ on a motor-driven micromanipulator by which they could be moved manually or pre-programed by a PC. During profiling the micromanipulator was software-driven and programmed to stop and measure at $100 \mu \mathrm{m}$ depth increments with $7 \mathrm{~s}$ delay at each depth before data sampling. The precision of positioning during profile measurements was a few micrometers on the vertical scale. Correction was made in the depth scale for the angle of the electrode. The electrode current was read on a picoamperemeter and continuously recorded on a strip-chart recorder for later evaluation. During profil-

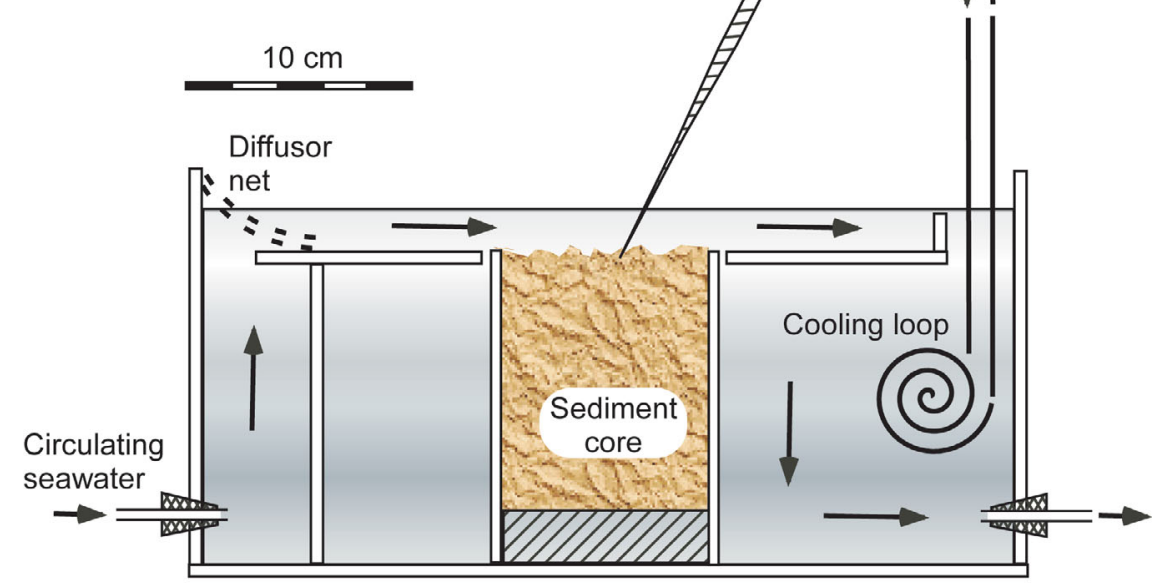

Fig. 2. Experimental flow aquarium for oxygen microprofile measurements. A core with intact sediment surface was positioned flush with a surrounding plate and a near-linear flow of seawater over the core provided a well-defined diffusive boundary layer. The sediment was kept at near in situ temperature in bottom water from the sampling site 
ing, the signal was furthermore transferred to an A-D converter and stored on a laptop PC. The continuous profiling indicated that there were no significant, unresolved oxygen gradients below the $100 \mu \mathrm{m}$ scale.

During oxygen profiling, the sediment surface was observed through a dissection microscope at low light intensity. It was checked that switching on and off the light did not affect the oxygen concentration at the sediment-water interface and, consequently, that there was no detectable benthic photosynthesis. The dissection microscope allowed an accurate determination of the position of the sediment surface relative to measured oxygen profiles. It also allowed the targeted positioning of the electrode relative to topographic features on the sediment surface or to faunal burrows in the sediment. Profiles were made at random and/or at selected positions on the surface, and several transects of profiles were analyzed in order to study the 2-dimensional vertical oxygen distribution. A total of 100 oxygen profiles were measured at 5 stations. The sediments were densely inhabited by polychaetes, bivalves and crustaceans, and in several cases time series of oxygen were measured within the faunal burrows to follow the dynamics of bioirrigation.

We analyzed 4 transects of oxygen distributions in the collected sediment cores in order to demonstrate the spatial heterogeneity in oxygen penetration and diffusive oxygen uptake. Oxygen profiles were measured along linear paths across sediment cores at $100 \mu \mathrm{m}$ depth resolution and $2 \mathrm{~mm}$ horizontal distance. Two-dimensional isopleth graphs of oxygen distribution were made using the software Surfer. The lateral variation of diffusive oxygen uptake was calculated for the same transects based on oxygen microprofiles.

Oxygen flux calculations. The accurate alignment of oxygen microprofiles relative to the sediment-water interface showed that the decrease in oxygen started at $0.5 \mathrm{~mm}$ or higher above the sediment surface and that a diffusive boundary layer (DBL) was blanketing the sediment surface (cf. Gundersen \& Jørgensen 1990, Santschi et al. 1991, Røy et al. 2002). The upper boundary of the DBL was defined as the intersection between the extrapolated linear $\mathrm{O}_{2}$ gradient in the DBL and the constant $\mathrm{O}_{2}$ value in the overlying water. The flux, $J$, of oxygen through the DBL was calculated from the oxygen gradient $\mathrm{d} C / \mathrm{d} z$ (where $C=\mathrm{O}_{2}$ concentration and $z=$ depth) and the molecular diffusion coefficient $D$ of oxygen at the in situ temperature of each station: $J=$ $D \mathrm{~d} C / \mathrm{d} z$ (Revsbech \& Jørgensen 1986). Values of $D$ were taken from Broecker \& Peng (1974) and recalculated to the relevant temperature and salinity. $D$ varied from $0.98 \times 10^{-5} \mathrm{~cm}^{2} \mathrm{~s}^{-1}$ at $-1.7^{\circ} \mathrm{C}$ in Storfjorden to $1.34 \times 10^{-5} \mathrm{~cm}^{2} \mathrm{~s}^{-1}$ at $7^{\circ} \mathrm{C}$ in Malangen Fjord.
Benthic fauna. Sediment for quantification of macrofauna was obtained from Stns SV-2 to SV-5 by a benthic flux chamber lander (Glud et al. 1998). After incubation experiments with the chamber on the seabed, the enclosed sediment of ca. $1 / 10 \mathrm{~m}^{2}$ and 10 to $15 \mathrm{~cm}$ depth was retrieved with the lander. The entire sediment volume was sieved through a $1 \mathrm{~mm}$ mesh sieve and all animals and intact faunal burrows were picked and fixed in $70 \%$ ethanol. The animals were grouped into classes, counted and measured. They were subsequently weighed, dried at $80^{\circ} \mathrm{C}$ until constant weight, reweighed, then ignited at $480^{\circ} \mathrm{C}$, and again weighed. From these data, the dry weight and organic content (measured as ignition loss) of the different faunal groups were calculated. All data were recalculated to $1 \mathrm{~m}^{2}$ of sea floor.

Faunal burrows of polychaetes and amphipods occurred as sediment-agglutinated tubes with sufficiently strength to survive sieving. It was noted whether the tubes appeared fresh and inhabited or were relict burrows. The latter were mostly encrusted by iron oxides and had a distinct brown coloration. The diameter and length of each tube was noted in order to calculate their combined length, surface area and volume on an areal basis.

Drop stones. The massive transport of glacier ice into the Svalbard fjords carries also large amounts of clastic debris that drops to the sea floor as the ice melts in summer. The resulting abundant occurrence of drop stones and pebbles in the fjord sediments provided an inevitable and continuous hazard to the fragile oxygen microelectrodes that challenged our frustration threshold. Pebbles and stones were obtained in the $1 \mathrm{~mm}$ sieves together with the fauna and were similarly measured and weighed to obtain a total volume of drop stones per $\mathrm{m}^{2}$ in the upper $10 \mathrm{~cm}$ of sediment.

\section{RESULTS}

\section{Sediment stations}

The sediments were silty and cohesive, with an organic carbon content ( $\mathrm{C}_{\text {org }}$ ) of 1.5 to $2.5 \mathrm{wt} \%$ (Glud et al. 1998). The amount of drop stones in the upper $10 \mathrm{~cm}$ of sediment ranged from 71 to $1188 \mathrm{~cm}^{3} \mathrm{~m}^{-2}$, with the lowest in Van Mijenfjorden and highest in Hornsund (Stn SV-2), where it corresponded to 0.07 to $1.2 \%$ of the total sediment volume. Further descriptions of the sediments and their mineralization processes are given in Kostka et al. (1999).

The infauna of the sediments comprised mostly polychaetes, bivalves and crustaceans (Table 2). At the Storfjorden station tube-dwelling amphipods (crustaceans) were particularly abundant, and also a few 
snails and sea anemones were found. The density of polychaetes outside burrow tubes ranged from 180 to 960 ind $\mathrm{m}^{-2}$. The number of polychaete tubes recognized as being inhabited was much higher, 440 to $3670 \mathrm{~m}^{-2}$ (Table 3). The latter corresponds to a density of 1 tube-dwelling polychaete per $3 \mathrm{~cm}^{2}$. The tubes had a mean outer diameter of $2.5 \mathrm{~mm}$ and an inner diameter of ca. $1.5 \mathrm{~mm}$. In addition to these, many polychaete tubes were uninhabited, and are thus termed relict tubes. Their numbers reached up to $12280 \mathrm{~m}^{-2}$ at Stn SV-4, or slightly more than $1 \mathrm{~cm}^{-2}$. Such densities obviously had a significant impact on the oxygen distribution in the sediment (see below).

When added up on an areal basis, the combined polychaete tubes comprised a length of 2360 to $11120 \mathrm{~m}$ $\mathrm{m}^{-2}$, a surface area of 1220 to $5780 \mathrm{~cm}^{2} \mathrm{~m}^{-2}$, and a volume of 60 to $278 \mathrm{~cm}^{3} \mathrm{~m}^{-2}$, being lowest in Van Mijenfjorden (Stn SV-3) and highest outside Hornsund (Stn SV-4) (Table 3). The abundant fauna was apparent from the density of polychaete tubes extending up to $1 \mathrm{~cm}$ above the sediment surface. Other sediments showed an irregular topography due to strong reworking of the surface by burrowing fauna (Fig. 3).

\section{Oxygen distributions}

Oxygen microprofiles showed that the thickness of the oxic sediment layer in the absence of bioirrigation, i.e. the primary oxygen zone, generally ranged from 3 to $10 \mathrm{~mm}$ with mean depths of 3.5 to $8 \mathrm{~mm}$. The thinnest oxic zone was found in Hornsund sediments and the deepest in Storfjorden. Examples of oxygen microprofiles in non-bioirrigated sediment are shown in Fig. 4 (Profiles A-I, B-I, D-I). Many of the profiles showed smooth depth trends, indicating that the oxygen distribution was governed by molecular diffusion between the oxic seawater and the oxygen-consuming sediment. Profiles B-I and D-I in Fig. 4 show extreme examples of shallow and deep diffusive oxygen penetration, respectively. The oxygen concentration generally started to drop ca. $0.5 \mathrm{~mm}$ above the sediment surface due to the diffusive boundary layer, which covers the sediment as a thin water film and follows the surface topography.

A large number of oxygen microprofiles showed subsurface oxygen peaks related to the burrows of polychaetes or crustaceans (Fig. 4, Profiles A-II to D-II). These peaks were most abundant in sediment cores with visible evidence of sediment
Table 2. Benthic macrofauna in sediments from 4 Svalbard stations. Data based on $0.1 \mathrm{~m}^{2}$ sediment box samples sieved through $1 \mathrm{~mm}$ mesh sieve. Data for Stn SV-2 are the mean of two $0.1 \mathrm{~m}^{2}$ samples. Other: snails and sea anemones

\begin{tabular}{|lcc|}
\hline $\begin{array}{l}\text { Stn } \\
\text { Type }\end{array}$ & $\begin{array}{c}\text { Density } \\
\text { (ind. } \mathrm{m}^{-2} \text { ) }\end{array}$ & $\begin{array}{c}\text { Ignition loss } \\
\left(\mathrm{g} \mathrm{m}^{-2}\right)\end{array}$ \\
\hline SV-2 Hornsund & & \\
Polychaetes & 510 & 3.34 \\
Bivalves & 370 & 7.31 \\
Crustaceans & 35 & 0.009 \\
Total & & 10.66 \\
SV-3 Van Mijenfjord & & \\
Polychaetes & 180 & 2.83 \\
Bivalves & 1050 & 4.82 \\
Crustaceans & 35 & 0.001 \\
Total & & 7.65 \\
SV-4 Hornsund O. & & \\
Polychaetes & 960 & 2.51 \\
Bivalves & 145 & 7.88 \\
Crustaceans & 22 & 0.011 \\
Total & & 10.40 \\
SV-5 Storfjorden & & \\
Polychaetes & 260 & 5.10 \\
Bivalves & & 6.84 \\
Crustaceans & 520 & 0.123 \\
Other & 35 & 7.60 \\
Total & 85 & 19.66 \\
\hline
\end{tabular}

reworking or with protruding polychaete tubes at the surface. The peaks showed that the animals in the burrows were actively pumping down oxygenated seawater for their respiration. As the computer-programmed profiling took 5 to $10 \mathrm{~min}$ per profile, concentrations often fluctuated over time and depth when the micro-

Table 3. Polychaete tubes and drop stones in sediments from 4 Svalbard stations. Box samples as in Table 2. Surface area and volume of polychaete tubes calculated from mean diameter of inhabited $(2.5 \mathrm{~mm})$ and relict $(1 \mathrm{~mm})$ tubes. Drop stone volumes calculated for upper $10 \mathrm{~cm}$ of sediment (volume data from Donald E. Canfield pers. comm.)

\begin{tabular}{|c|c|c|c|c|c|}
\hline $\begin{array}{l}\text { Stn } \\
\text { Type }\end{array}$ & $\begin{array}{l}\text { Density } \\
\text { (ind. } \mathrm{m}^{-2} \text { ) }\end{array}$ & $\begin{array}{l}\text { Length } \\
\left(\mathrm{cm} \mathrm{m}^{-2}\right)\end{array}$ & $\begin{array}{l}\text { Surface area } \\
\left(\mathrm{cm}^{2} \mathrm{~m}^{-2}\right)\end{array}$ & $\begin{array}{c}\text { Volume } \\
\left(\mathrm{cm}^{3} \mathrm{~m}^{-2}\right)\end{array}$ & $\begin{array}{l}\text { Drop stones } \\
\left(\mathrm{cm}^{3} \mathrm{~m}^{-2}\right)\end{array}$ \\
\hline \multicolumn{6}{|c|}{ SV-2 Hornsund } \\
\hline Inhabited & 1580 & 3290 & 2580 & 37 & \\
\hline Relict & 9240 & 4720 & 1480 & 162 & \\
\hline Total & & 8010 & 4060 & 199 & 1188 \\
\hline \multicolumn{6}{|c|}{ SV-3 Van Mijenfjord } \\
\hline Inhabited & 440 & 1010 & 790 & 11 & \\
\hline Relict & 490 & 1350 & 430 & 49 & \\
\hline Total & & 2360 & 1220 & 60 & 71 \\
\hline \multicolumn{6}{|c|}{ SV-4 Hornsund O. } \\
\hline Inhabited & 2100 & 4870 & 3820 & 49 & \\
\hline Relict & 12280 & 6250 & 1960 & 239 & \\
\hline Total & & 11120 & 5780 & 278 & 527 \\
\hline \multicolumn{6}{|c|}{ SV-5 Storfjorden } \\
\hline Inhabited & 3670 & 4770 & 3740 & 10 & \\
\hline Relict & 2720 & 1310 & 410 & 234 & \\
\hline Total & & 6080 & 4150 & 244 & 660 \\
\hline
\end{tabular}




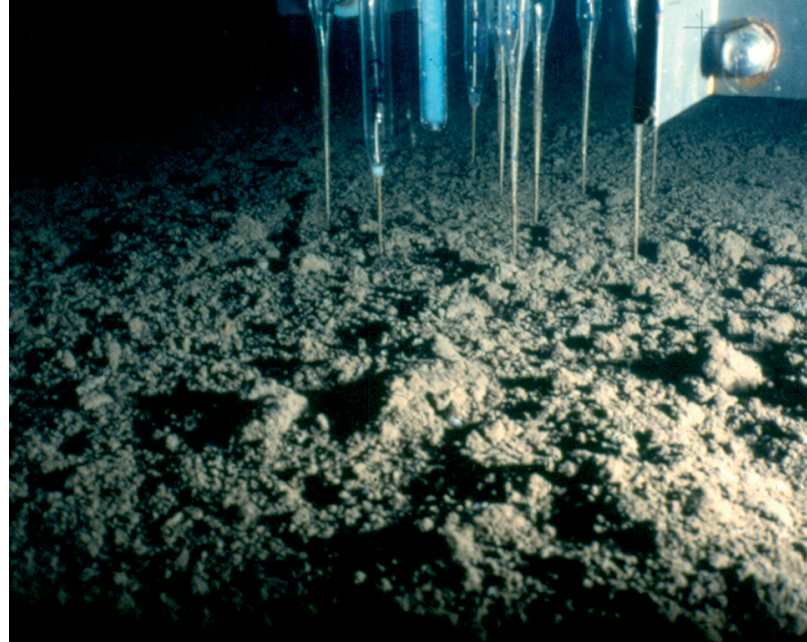

Fig. 3. In situ photograph of sediment surface at Stn SV-3, Van Mijenfjorden, showing sediment topography caused by burrowing fauna. The camera was mounted on a free-falling benthic lander equipped with multiple microelectrodes; a part of the lander structure is visible in the upper right corner. Width of the image is ca. $25 \mathrm{~cm}$ at the location of microelectrodes

electrode passed close to ventilated burrows. Fig. 4 (Profile C-I) shows an example of such a 'noisy' profile.

On several occasions the microelectrode was positioned within a polychaete tube for an extended period in order to analyze the rhythm of pumping and oxygen transport into the tube. Such measurements showed that the oxygen concentration fluctuated strongly within the tube, sometimes showing regular oscillations, at other times gradual and irregular changes. The amplitude of oscillations could cover a range as large as 10 to $90 \%$ of seawater $\mathrm{O}_{2}$ saturation. Importantly, the oxygen concentration within a tube was often higher than that of the surrounding oxygen gradient at the same depth, but sometimes also lower. Thus, the tubes were occasionally oxygen-depleted microenvironments within the oxic sediment.

Transects of oxygen distribution were analyzed in 4 cores from the 3 stations in Hornsund, Van Mijenfjorden and Storfjorden. The data are shown as isopleths in Fig. 5 together with the calculated oxygen fluxes across the sediment-water interface.

Stn SV-2 from Hornsund showed the most shallow oxygen penetration, tapering down from 5.5 to $3.5 \mathrm{~mm}$ along the transect (Fig. 5, Transect A-II, from left to right). A narrow oxic zone indicates a high oxygen consumption rate in the surface sediment. Accordingly, the diffusive oxygen uptake increased along the transect from $6 \mathrm{mmol} \mathrm{O}_{2} \mathrm{~m}^{-2} \mathrm{~d}^{-1}$ to a maximum of $25 \mathrm{mmol} \mathrm{O}_{2} \mathrm{~m}^{-2} \mathrm{~d}^{-1}$ (Fig. 5, Transect A-I), the highest detected at any of the stations. At the transect position of $10 \mathrm{~mm}$, the transect crossed a polychaete tube, visible as a subsurface peak of oxygen at $8 \mathrm{~mm}$ depth within the otherwise anoxic zone.
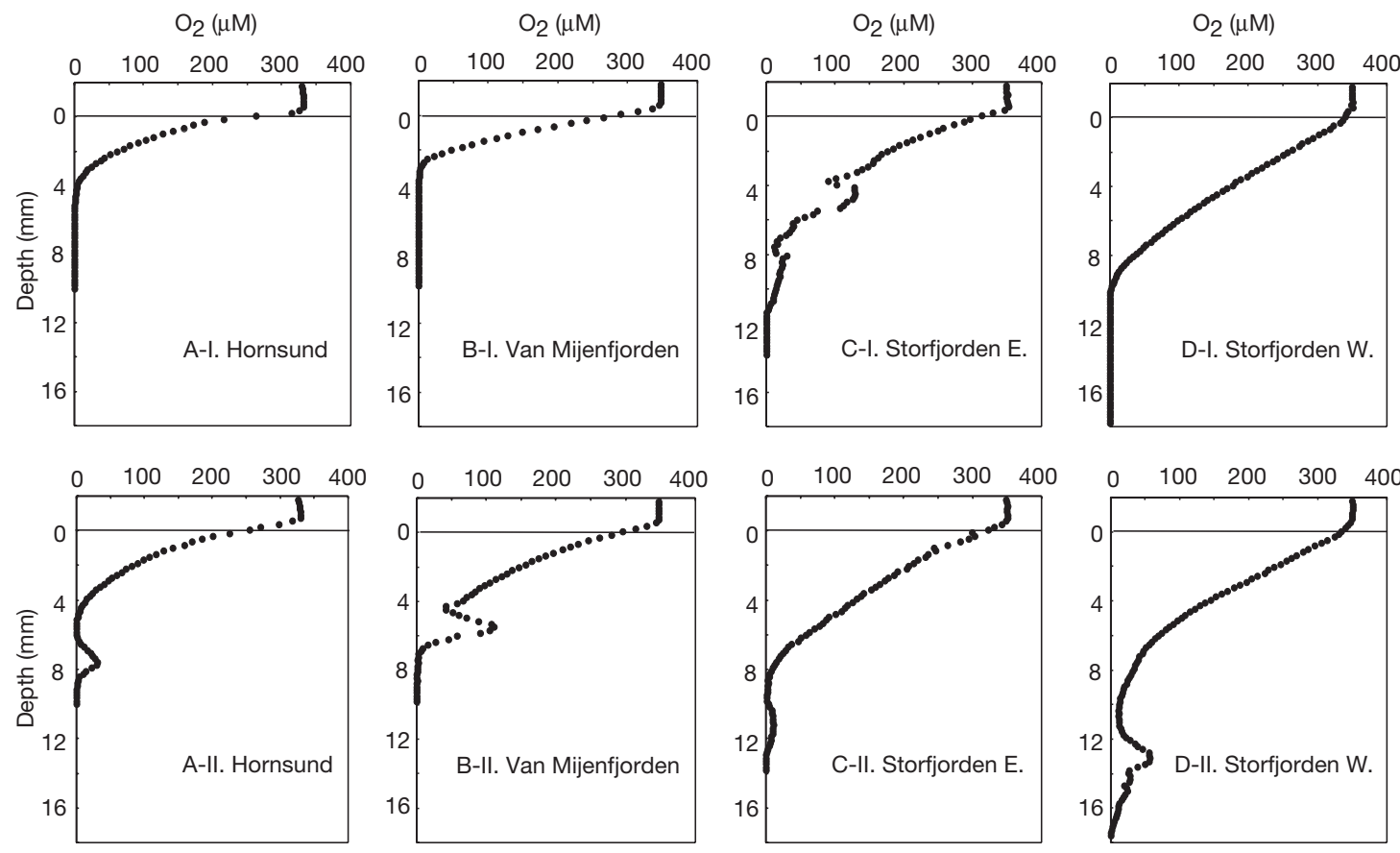

Fig. 4. Oxygen microprofiles selected from 4 sediment stations along SW coast of Svalbard. Upper panels show examples of oxygen penetration controlled mostly by molecular diffusion; irregular profile C-I, however, shows evidence of irrigation of a polychaete burrow. Lower panels show examples of oxygen peaks in lower part of the oxic zone reflecting irrigated burrows 

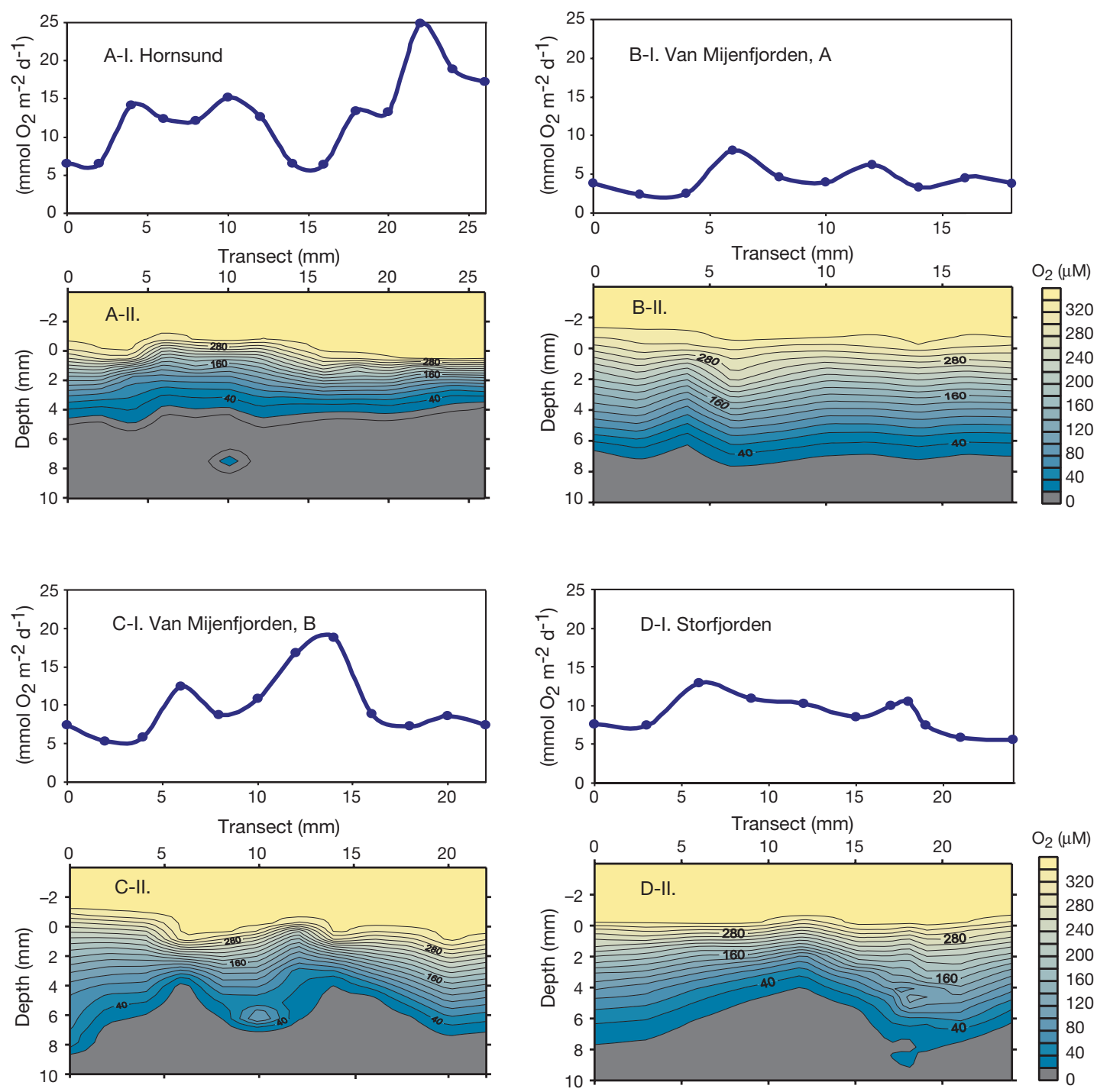

Fig. 5. Vertical transects of oxygen distribution measured in 4 sediment cores (A to D) from 3 stations: (A) Hornsund, (B) and (C) Van Mijenfjorden; (D) Storfjorden. Associated diffusive oxygen fluxes across sediment-water interface were calculated and are shown as smooth curves (A-I to D-I). The 2-dimensional oxygen transects are shown as $\mathrm{O}_{2}$ isopleths with $20 \mu \mathrm{M}$ increments (A-II to D-II). Position of sediment surface corresponds approximately to the uppermost isopleth; gray shading indicates $<20 \mu \mathrm{M} \mathrm{O}_{2}$ and corresponds largely to the anoxic zone. Vertical and horizontal scales are not isometric

We analyzed 2 oxygen transects from Stn SV-3 in Van Mijenfjorden in 2 different sediment cores from the same multicorer cast. They differed strongly and demonstrated the heterogeneous distribution of tubedwelling polychaetes on a decimeter scale. The first transect crossed sediment with little evidence of fauna and showed a very uniform oxygen penetration, yet the calculated diffusive oxygen uptake varied 2-fold (Fig. 5, Transects B-I and B-II). The other transect crossed several burrows positioned at both ends and in the middle of the section (Fig. 5, Transect C-II). The middle burrow was evident as an oxygen peak at $6 \mathrm{~mm}$ depth, while the 2 peripheral burrows were indicated by a deeper oxygen penetration of 7 to $10 \mathrm{~mm}$. In between the burrows, at 6 and $14 \mathrm{~mm}$ along the transect, oxygen penetration was only $4 \mathrm{~mm}$. These positions showed peaks in diffusive oxygen fluxes at the sediment surface (Fig. 5, Transect C-I). An explanation for this distribution could be that bioirrigation in the burrows increases the oxygen concentration in the immediate surroundings and thereby reduces the vertical oxygen gradient. In between the burrows, accumulated fecal material from the polychaetes may enhance the oxygen uptake at the sediment surface. Accordingly, the overall oxygen uptake was about 2fold higher in the sediment with polychaete burrows than in the nearby sediment without burrows. It should be noted that the sediment with burrows had an addi- 
tional oxygen uptake through bioirrigation that is not accounted for by the diffusive flux calculations. Thus, the total (diffusive plus advective) oxygen uptake in Transect $\mathrm{C}$ may in reality be highest at the positions of the polychaete tubes.

In the transect from Storfjorden, several polychaete tubes at positions 17 and $18 \mathrm{~mm}$ along the transect provided subsurface oxygen maxima at 5 and $9 \mathrm{~mm}$ depth (Fig. 5, Transect D-II). The calculated diffusive oxygen uptake, however, also showed a local maximum at those positions (Fig. 5, Transect D-I). Possibly, the cluster of polychaetes accumulated degradable organic matter at the sediment surface and thereby enhanced the DBL flux of oxygen. Thus, the spatial distribution of diffusive oxygen fluxes in relation to faunal burrows is obviously complex when viewed on a 2-dimensional scale.

The diffusive oxygen uptake rates of sediments calculated from oxygen microprofiles are summarized in Table 4. Mean rates are calculated for each station based on a total data set of 87 microprofiles. An additional 13 microprofiles showed non-steady-state conditions and other irregularities that made them unsuited for DBL flux calculations. The highest diffusive oxygen uptake was found in Hornsund on the west coast of Spitsbergen, the lowest in Storfjorden on the SE side. Water depths at the 2 sites were similar, whereas the organic carbon content of the sediment was highest in Storfjorden (2.5\% $\mathrm{C}_{\text {org }}$, versus $1.5 \% \mathrm{C}_{\text {org }}$ in Hornsund), in contrast to the oxygen uptake rates. In accordance with the oxygen microprofiles in Figs. 4 \& 5 and the heterogeneous distribution of fauna, the standard deviation of calculated oxygen fluxes was large. Nevertheless, because to the large number of profiles, the differences in the mean fluxes are statistically significant.

\section{DISCUSSION}

The diffusive oxygen uptake calculated for 5 stations is compared in Table 4 to the total oxygen uptake measured by an in situ flux chamber or in retreived cores by

Table 4. Diffusive and total oxygen uptake $\left(\mathrm{mmol} \mathrm{m}^{-2} \mathrm{~d}^{-1}\right)$ and depth of oxygen penetration (DOP) in sediments. n: number of profiles per station. -: not measured. Laboratory data from Glud et al. (1998)

\begin{tabular}{|c|c|c|c|c|c|c|c|}
\hline \multirow[t]{2}{*}{ Stn } & \multirow{2}{*}{ Area } & \multicolumn{3}{|c|}{ Diffusive uptake } & \multicolumn{2}{|c|}{ Total uptake } & \multirow{2}{*}{$\begin{array}{l}\text { DOP } \\
(\mathrm{mm})\end{array}$} \\
\hline & & Mean & $\mathrm{SD}$ & $\mathrm{n}$ & In situ & Laboratory & \\
\hline SV-1 & Malangen Fjord & 9.4 & 2.4 & 4 & - & 4.7 & $6-8$ \\
\hline SV-2 & Hornsund & 13.4 & 3.9 & 24 & 16.4 & 8.1 & $3-5$ \\
\hline SV-3 & Van Mijenfjord & 7.7 & 4.1 & 23 & 13.1 & 4.2 & $6-8$ \\
\hline SV-5 & Storfjorden & 8.6 & 2.3 & 19 & 9.0 & 3.6 & $6-9$ \\
\hline SV-6 & Storfjorden W & 2.8 & 0.7 & 13 & - & - & $8-11$ \\
\hline
\end{tabular}

Glud et al. (1998). At all stations where comparable data are available, the calculated diffusive uptake was higher than the total uptake measured in laboratoryincubated cores by Glud et al. (1998) but lower than the total uptake measured in situ using a flux chamber lander. The high oxygen uptake measured in chambers in situ presumably includes the undisturbed pumping activity and respiration by the entire benthic fauna. Because of the general requirement for 'undisturbed' cores, laboratory incubations tend to exclude sediments with disturbance due to fauna. The disturbance may be due to, e.g., tough polychaete tubes being pulling down by the core liner, to water draining out through large burrows, or to the core liner cutting through larger tubes - and perhaps through their inhabitants. Sediments with particularly dense fauna thereby tend to be excluded. In the present study, such cores were included in the measurements, although occasionally only part of the sediment surface was intact. This, however, should not affect the oxygen penetration and flux in the central, undisturbed area of the sediment surface. Furthermore, the incubation in a flow aquarium with oxygenated seawater flowing over the core generated a DBL of 0.5 to $0.6 \mathrm{~mm}$, thinner than that measured in laboratory-incubated cores by Glud et al. (1998). Because of the weaker stirring in those cores, the DBL was relatively thick, 0.9 to $1.4 \mathrm{~mm}$. The DBL thickness affects the steepness of the oxygen microprofile and thus the oxygen flux across the sediment-water interface. Using a benthic lander equipped with microsensors (cf. Fig. 3), Glud et al. (1998) measured DBL thicknesses of 0.5 to $0.8 \mathrm{~mm}$ in situ, close to the values in our flow aquarium. They did not find significant differences, however, between the diffusive oxygen uptake calculated from in situ- or from laboratory-measured microprofiles.

The calculated diffusive oxygen uptake is high relative to the total oxygen uptake measured by in situ chamber incubations. The difference indicates that bioirrigating fauna should contribute 5 to $70 \%$ to the total oxygen uptake, corresponding to the difference between the diffusive and the total oxygen uptake. Examples of faunal contributions to the oxygen uptake in similar cold, soft-bottom shelf sediments range from $15 \%$ in the NW Barents Sea (Piepenburg et al. 1995) to $33 \%$ in Antarctic waters at the South Orkney Islands (Nedwell \& Walker 1995), 10 to $60 \%$ in a high Arctic Sound of NE Greenland (Glud et al. 2000), and 60 to $70 \%$ in the north Bering Sea (Blackburn 1987).

The diffusive oxygen uptake of Svalbard fjord sediments calculated in this study ranged from 2.8 to $13.4 \mathrm{mmol} \mathrm{m}^{-2} \mathrm{~d}^{-1}$, with a mean of $8 \mathrm{mmol} \mathrm{O}_{2} \mathrm{~m}^{-2} \mathrm{~d}^{-1}$. This rate of 
oxygen uptake is close to that in other studies in Arctic coastal seas at comparable water depth measured by sediment core incubations or by in situ chambers. Thus, in shelf sediments east of Svalbard, Pfannkuche \& Thiel (1987) found an $\mathrm{O}_{2}$ uptake of 3.2 to $11.9 \mathrm{mmol} \mathrm{m}^{-2} \mathrm{~d}^{-1}$, while Hulth et al. (1994) measured 3.9 to $11.2 \mathrm{mmol} \mathrm{m}^{-2}$ $\mathrm{d}^{-1}$. Rates measured off Newfoundland by Pomeroy et al. (1991) were $8.4 \mathrm{mmol} \mathrm{m}^{-2} \mathrm{~d}^{-1}$. Data summarized by Glud et al. (1998) show that these data are also close to oxygen uptake rates in shelf sediments of temperate latitudes. The benthic respiration in polar shelf seas is thus of the same magnitude as in warmer regions.

If the measured diffusive oxygen uptake were representative of the entire year, the mean annual oxygen consumption would be $2.9 \mathrm{~mol} \mathrm{O}_{2} \mathrm{~m}^{-2} \mathrm{yr}^{-1}$. With an assumed respiratory quotient of $1 \mathrm{~mol} \mathrm{O}_{2} \mathrm{~mol}^{-1} \mathrm{C}_{\text {org }}$ oxidized, the equivalent carbon oxidation would be $35 \mathrm{~g} \mathrm{C} \mathrm{m}^{-2} \mathrm{yr}^{-1}$. Estimates of the annual primary production in coastal waters off Svalbard and in the Barents Sea fall mostly in the range of 25 to $150 \mathrm{~g} \mathrm{C} \mathrm{m}^{-2}$ $\mathrm{yr}^{-1}$ (Eilertsen et al. 1989, Hop et al. 2002), with $110 \mathrm{~g} \mathrm{C}$ $\mathrm{m}^{-2} \mathrm{yr}^{-1}$ as a long-term average for the Barents Sea (Sakshaug 1997). If the productivity in the open, deep fjords is similar to that in the surrounding ocean, then benthic mineralization would account for a third of the annual phytoplankton production. Andreassen et al. (1996) measured vertical particle fluxes on the shelf off NW Svalbard of 18 to $76 \mathrm{mg} \mathrm{C} \mathrm{m}{ }^{-2} \mathrm{~d}^{-1}$, corresponding to 7 to $28 \mathrm{~g} \mathrm{C} \mathrm{m}^{-2} \mathrm{yr}^{-1}$, i.e. somewhat lower than the benthic mineralization of organic carbon measured here during the Arctic summer.

The coastal sediments of Svalbard are densely populated by burrowing fauna that affect the spatial distribution of oxygen and mineralization rates. About 15\% of the oxygen profiles measured showed irregularities related to faunal burrows and activities. The total density of burrows, inhabited and relict, was up to $1 \mathrm{~cm}^{-2}$ (Table 3). Each of these was presumably surrounded by a narrow cylinder of oxic tube wall and sediment, thereby expanding the oxic-anoxic interface area and the oxygen flux to the sediment. The subsurface oxygen peaks often had a vertical extension of 3 to $4 \mathrm{~mm}$ (Fig. 4, Profiles A-II to D-II). It is, however, difficult to estimate the angle at which the microelectrode passed the tubes or how close the microelectrode came to each tube. The calculated surface area of inhabited and relict tubes was 1220 to $5780 \mathrm{~cm}^{2} \mathrm{~m}^{-2}$ (Table 3). This is equivalent to a 12 to $58 \%$ increase in oxygen-exposed sediment surface. Since some of this additional oxic surface is situated within the primary oxic zone, the effect on the total oxygen flux may be somewhat less. A more detailed calculation for Stn SV-5 in Storfjorden illustrates this. The calculation provides an upper limit for the oxygen distribution in the suboxic sediment.
The combined length of polychaete tubes was $4770 \mathrm{~cm} \mathrm{~m}^{-2}$ for inhabited tubes and $1310 \mathrm{~cm} \mathrm{~m}^{-2}$ for relict tubes. The length of inhabited tubes, and thus the depth to which they may guide oxic seawater into the sediment, ranged from 0.5 to $8 \mathrm{~cm}$ with a mean length of $1.3 \mathrm{~cm}$ (Stn SV-5) to $2.3 \mathrm{~cm}$ (Stn SV-3) for the 4 stations. The primary oxygen penetration depth at SV-5 was 6 to $9 \mathrm{~mm}$ and thus, on average, half of each tube penetrated down into the anoxic sediment. Based on the width of the many subsurface oxygen peaks measured, we estimate that oxygen may have penetrated ca. $1 \mathrm{~mm}$ outside of the tubes. With a diameter of $2.5 \mathrm{~mm}$ for inhabited tubes, the surrounding cylinder of oxic sediment is thus $4.5 \mathrm{~mm}$ in diameter. As the total tube length below the primary oxic zone was $0.5 \times$ $4770 \mathrm{~cm} \mathrm{~m}^{-2}$, the tube-related volume of oxic sediment (including tube wall) within the suboxic zone is $(0.5 \times$ $4770 \times \pi \times 0.225 \times 0.225) 380 \mathrm{~cm}^{3} \mathrm{~m}^{-2}$. This may be compared with the total volume of the primary oxygen zone. With a mean depth of the oxic zone of $7.5 \mathrm{~mm}$ (cf. Table 4), its volume was $7500 \mathrm{~cm}^{3} \mathrm{~m}^{-2}$. The additional oxic sediment below the primary oxygen zone thus corresponded to $5 \%$ for Stn SV-5. For the other stations with available oxygen microprofiles, the additional oxic sediment associated with polychaete tubes was $10 \%$ for SV-2 and $2 \%$ for SV-3.

Relict tubes may also contribute to the advective oxygen influx by a passive, flow-induced flushing (cf. Aller \& Aller 1986, Munksby et al. 2002). The passive flushing of these narrow tubes was probably less efficient than that of the inhabited tubes and the contribution to deep oxygen injection correspondingly less, maybe 1 to $2 \%$. From this we conclude that the diffusive oxygen flux out of faunal burrows provided only a minor addition to the total oxygen uptake, in spite of the abundance of burrows. On the other hand, the focused injection of oxygen down into the suboxic sediment may play an important role in the biogeochemistry of that zone, e.g. for the oxidation of reduced iron and sulfur species. The iron oxide-encrusted walls of relict polychaete tubes indicate this role.

In addition to the sediment respiration described above, the respiration by the bioirrigating animals also added to the total oxygen uptake. Furthermore, the diffusive flux calculations do not take into account the sediment surface topography which adds to the DBL area and thus to the total flux. Unless the sediment has an extraordinarily rough surface relief, however, this correction is generally $<10 \%$ for muddy sediments (Røy et al. 2002, Glud et al. 2003).

During the measurements of oxygen microprofiles we also searched for anoxic microenvironments within the oxic surface zone of the sediment. Given the very fine tip of the oxygen microelectrodes, with only 5 to $20 \mu \mathrm{m}$ diameter, these should be able to penetrate local 
oxygen minima if such existed within the bulk sediment. Of the 100 oxygen profiles, only 5 showed local minima. These appeared to occur in the vicinity of inhabited polychaete tubes, where oxygen profiles were irregular and fluctuating (e.g. Fig. 5, Transect C-I). Profiling close to biogenic structures is often avoided during laboratory microsensor studies as the profiles do not represent the 'undisturbed' sediment, and therefore such profiles are generally undersampled. However, in our case the slowly progressing electrode tip recorded not only the spatial distribution but also the temporal fluctuations in oxygen arising from alternating pumping and resting by the inhabiting polychaete. We conclude that the polychaete tube is not only a source of oxygen to the suboxic sediment during active irrigation by the worm, but is also a microenvironment of particularly high oxygen consumption. Thus, during inactive periods of the polychaete, the tube itself and the sediment immediately surrounding the tube may develop a local oxygen minimum. The high oxygen consumption of the polychaete tubes may be caused by enhanced bacterial respiration due to mucus secretion by the polychaete and the trapping of organic detritus along the tube wall. The tubeassociated oxygen minima tended to occur, or be particularly visible, in the lower part of the oxic zone. In all recognized occurrences, however, they were not completely depleted of oxygen. We found no other evidence of anoxic microenvironments.

Acknowledgements. We thank Donald E. Canfield for organizing and leading the cruise to Svalbard and the captain and crew of RV 'Jan Mayen' as well as Paul Wassmann for very helpful cooperation. We also thank the participating scientists for support during sampling and for a stimulating working atmosphere on board. Anonymous reviews of the manuscript were very constructive and helpful. This study was supported by the Max Planck Society. B.B.J. was supported post-cruise by the Fonds der Chemischen Industrie.

\section{LITERATURE CITED}

Aller JY, Aller RC (1986) Evidence for localized enhancement of biological activity associated with tube and burrow structures in deep-sea sediments at the HEBBLE site, western North Atlantic. Deep-Sea Res 33:133-165

Andreassen I, Nöthig EM, Wassmann P (1996) Vertical particle flux on the shelf off northern Spitzbergen, Norway. Mar Ecol Prog Ser 137:215-228

Arnosti C, Jørgensen BB (2003) High activity and low temperature optima of extracellular enzymes in Arctic sediments: implications for carbon cycling by heterotrophic microbial communities. Mar Ecol Prog Ser 249:15-24

Atkinson EG, Wacasey JW (1987) Sedimentation in Arctic Canada: particulate organic carbon flux to a shallow marine benthic community in Frobisher Bay. Polar Biol 8:3-7

Blackburn TH (1987) Microbial food webs in sediments. In: Sleigh MA (ed) Microbes in the sea. Ellis-Horwood,
Chichester, p 39-58

Broecker WS, Peng TH (1974) Gas exchange rates between air and sea. Tellus 26:21-35

Eilertsen HC, Taasen JP, Weslawski JM (1989) Phytoplankton studies in the fjords of West Spitzbergen: physical environment and production in spring and summer. J Plankton Res 11:1245-1260

Glud RN, Holby O, Hoffmann, F, Canfield DE (1998) Benthic mineralization and exchange in Arctic sediments (Svalbard, Norway). Mar Ecol Prog Ser 173:237-251

Glud RN, Riisgaard-Petersen N, Thamdrup B, Fossing H, Rysgaard S (2000) Benthic carbon mineralization in a high Arctic Sound (Young Sound, NE Greenland). Mar Ecol Prog Ser 206:59-71

Glud RN, Gundersen JK, Røy H, Jørgensen BB (2003) Seasonal dynamics of benthic $\mathrm{O}_{2}$ uptake in a semienclosed bay: importance of diffusion and faunal activity. Limnol Oceanogr 48:1265-1276

Gundersen JK, Jørgensen BB (1990) Microstructure of diffusive boundary layers and the oxygen uptake of the sea floor. Nature 345:604-607

Hebbeln D, Wefer G (1991) Effects of ice coverage and icerafted material on sedimentation in the Fram Strait. Nature 350:409-411

Hop H, Pearson T, Hegseth EN, Kovacs KM and 24 others (2002) The marine ecosystem of Kongsfjorden, Svalbard. Polar Res 21:167-208

Hulth S, Blackburn TH, Hall POJ (1994) Arctic sediments (Svalbard): consumption and microdistribution of oxygen. Mar Chem 46:293-316

Knoblauch C, Jørgensen BB (1999) Effect of temperature on sulfate reduction, growth rate, and growth yield in 5 psychrophilic sulfate-reducing bacteria from Arctic sediments. Environ Microbiol 1:457-467

Kostka JE, Thamdrup B, Glud RN, Canfield DE (1999) Rates and pathways of carbon oxidation in permanently cold Arctic sediments. Mar Ecol Prog Ser 180:7-21

Munksby N, Benthien M, Glud RN (2002) Flow-induced flushing of relict tube structures in the central Skagerrak (Norway). Mar Biol 141:939-945

Nedwell DB, Walker TR (1995) Sediment-water fluxes of nutrients in an Artarctic coastal environment: influence of bioturbation. Polar Biol 15:57-64

Nedwell DB, Walker TR, Ellis-Evans JC, Clarke A (1993) Measurements of seasonal rates and annual budgets of organic carbon fluxes in an Antarctic coastal environment at Signy Island, South Orkney Islands, suggest a broad balance between production and decomposition. Appl Environ Microbiol 59:3989-3995

Pfannkuche O, Thiel H (1987) Meiobenthic stocks and benthic activity on the NE-Svalbard shelf and in the Nansen basin. Polar Biol 7:253-266

Piepenburg D, Blackburn TH, von Dorrien CF, Gutt J and 6 others (1995) Partitioning of benthic community respiration in the Arctic (northwestern Barents Sea). Mar Ecol Prog Ser 118:199-213

Pomeroy LR, Wiebe WJ, Deibel D, Thompson RJ, Rowe GT, Pakulski JD (1991) Bacterial response to temperature and substrate concentration during the Newfoundland spring bloom. Mar Ecol Prog Ser 75:143-159

Revsbech NP (1989) An oxygen microelectrode with a guard cathode. Limnol Oceanogr 34:474-478

Revsbech NP, Jørgensen BB (1986) Microelectrodes: their use in microbial ecology. In: Marshall KH (ed) Advances in microbial ecology, Vol 9. Plenum Press, New York, p 293-352

Røy H, Hüttel M, Jørgensen BB (2002) The role of small scale 
sediment topography for oxygen flux across the diffusive boundary layer. Limnol Oceanogr 47:837-847

Rysgaard S, Finster K, Dahlgaard H (1996) Primary production, nutrient dynamics and mineralization in a northeastern Greenland fjord during the summer thaw. Polar Biol 16:497-506

Rysgaard S, Thamdrup B, Risgaard-Petersen N, Fossing $H_{\text {, }}$ Berg P, Christensen PB, Dalsgaard T (1998) Seasonal carbon and nutrient mineralization in a high-Arctic coastal marine sediment, Young Sound, Northeast Greenland. Mar Ecol Prog Ser 175:261-276

Sakshaug E (1997) Biomass and productivity distributions and their variability in the Barents Sea. ICES J Mar Sci 54:341-350

Sakshaug E, Bjørge A, Gulliksen B, Loeng H, Mehlum F (1994) Structure, biomass distribution, and energetics of the pelagic ecosystem in the Barents Sea: a synopsis. Polar Biol 14:405-411

Editorial responsibility: Otto Kinne (Editor-in-Chief), Oldendorf/Luhe, Germany
Santschi PH, Anderson RF, Fleisher MQ, Bowles W (1991) Measurements of diffusive sublayer thicknesses in the ocean by alabaster dissolution and their implications for the measurements of benthic fluxes. J Geophys Res 96: 10641-10657

Thamdrup B, Fleischer S (1998) Temperature dependence of oxygen respiration, nitrogen mineralization, and nitrification in Arctic sediments. Aquat Microb Ecol 15:191-199

Thamdrup B, Fossing H, Jørgensen BB (1994) Manganese, iron, and sulfur cycling in a coastal marine sediment, Aarhus Bay, Denmark. Geochim Cosmochim Acta 58: 5115-5129

Thamdrup B, Hansen J, Jørgensen BB (1998) Temperature dependence of aerobic respiration in a coastal sediment. FEMS Microbiol Ecol 25:189-200

Wassmann P, Andersen I, Reigstad M, Slagstad D (1996) Pelagic-benthic coupling in the Nordic seas: the role of episodic events. Mar Ecol 17:447-471

Submitted: July 6, 2004; Accepted: December 7, 2004 Proofs received from author(s): May 2, 2005 